\title{
PATIENTS WITH DIFFERENT METASTATIC MALIGNANCIES AND ACUTE MYOCARDIAL INFARCTION WITH ST SEGMENT ELEVATION TREATED WITH PRIMARY PERCUTANEOUS CORONARY INTERVENTION
}

\author{
Sonja Šalinger-Martinović1,2, Dragana Stanojević1, Zorica Dimitrijević1,2, Tomislav Kostić1,2, \\ Snežana Ćirić-Zdravković1,2, Branislava Ivanović ${ }^{3,4}$, Stefan Momčilovićs
}

\begin{abstract}
Cardiovascular diseases and malignancies are still the most potential causes of lethal event. These diseases very often co-exist in elderly population and arise from the same risk factors such as tobacco use. Improvement in malignancy treatment prolongs life, but may be harmful, due to hemo and radiotherapy regimen. Many chemotherapeutic agents are associated with angina and myocardial infarction, while radiotherapy is associated with coronary artery disease through direct endothelial injury. In addition, the prothrombotic and inflammatory status in metastatic malignancies promote the development of atherosclerotic plaques and thrombus formation in coronary arteries. In this paper, we present two cases of patients with different metastatic malignancies with acute myocardial infarction with ST segment elevation treated with primary percutaneous coronary intervention (PPCI) and with different short-term outcome.
\end{abstract}

Acta Medica Medianae 2020;59(2):125-131.

Key words: malignancy, myocardial infarction, PCI, outcome

\footnotetext{
${ }^{1}$ Clinic of Cardiovascular Diseases, Clinical Center of Niš, Niš, Serbia

${ }^{2}$ University of Niš, Faculty of Medicine, Department of

Cardiology, Niš, Serbia.

${ }^{3}$ University of Belgrade, Faculty of Medicine, Belgrade, Serbia.

${ }^{4}$ Clinic for Cardiology, Clinical Center of Serbia, Belgrade,

Serbia.

${ }^{5}$ University of Niš, Faculty of Medicine, Niš, Serbia.
}

Contact: Sonja Šalinger-Martinović

48 Dr. Zoran Djindjić Blvd., 18000 Niš, Serbia

E-mail: sonja.salinger@gmail.com motherapy and/or radiation that can influence early atherosclerosis (3). In such patients, PCI is of great significance in treatment, especially in cases of metastatic malignancies.

In this paper, we report two patients with STelevation myocardial infarction (STEMI) and metastatic malignancies who were on different chemotherapy regimens and underwent primary PCI in our cath lab.

\section{Case presentations}

\section{Case 1}

A man, 50 years old, with nausea and abdominal pain, was admitted to hospital in May 2017. Physical examination revealed abdomen larger than normal and palpable tumorous formation. Huge retroperitoneal tumor was detected on MSCT scan, spreading from left inguinal region to lien, pressing urine bladder, stomach and intestines. A sample of a tissue was taken out by laparotomy, and subsequent pathohistological examination showed that the patient has atypical lipomatous tumor (ALT)/well differentiated liposarcoma (WLS). This was a clear indication for chemotherapy, and the patient was put on ifosfamidic protocol. Another MSCT scan in August 2017 revealed metastatic formations in cerebral regions, both frontal and temporal, and in the cerebellar region. Therefore, the second chemotherapy protocol was introduced in September 2017. 
A month later, in October 2017, patient complained to chest pain, with propagation to shoulders and back, and therefore was referred to primary PCI center. ECG on admission showed ST-segment elevation in leads II, III, a VF and ST-segment depression in leads V3-V6, with R-wave rising. These findings indicated infero-posterior STEMI and the patient received a loading dose of Clopidogrel (600 mg), Aspirin (300 mg), and Heparin (7000 IV). Due to the presence of oversized and tough abdomen covering the groins, the only possible approach in this case was trans-radial approach. Culprit lesion was detected in the distal right coronary artery (RCA), with significant lesions in the mid and proximal portion of the RCA, along with some nonsignificant lesions in the left anterior descending artery (LAD), and the left circumflex branch (LCX) (Figure 1 and 2).

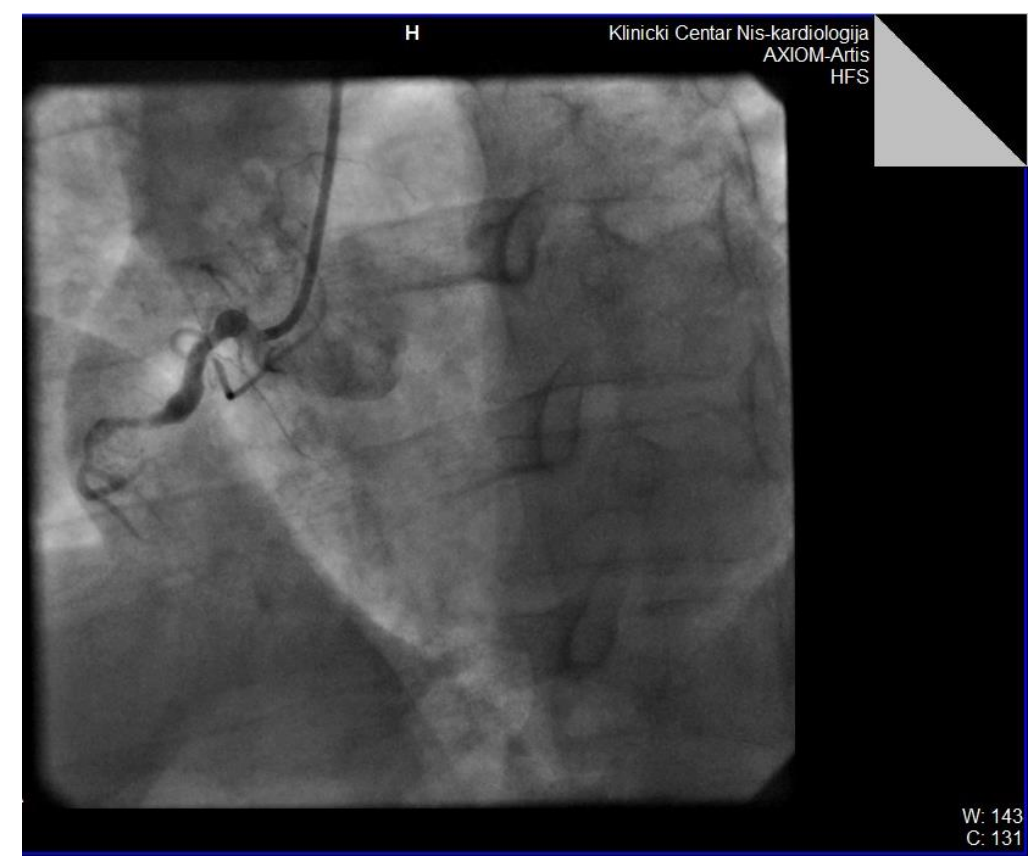

Figure 1. Right coronary artery with culprit lesion in the distal and significant lesions in the mid and proximal part

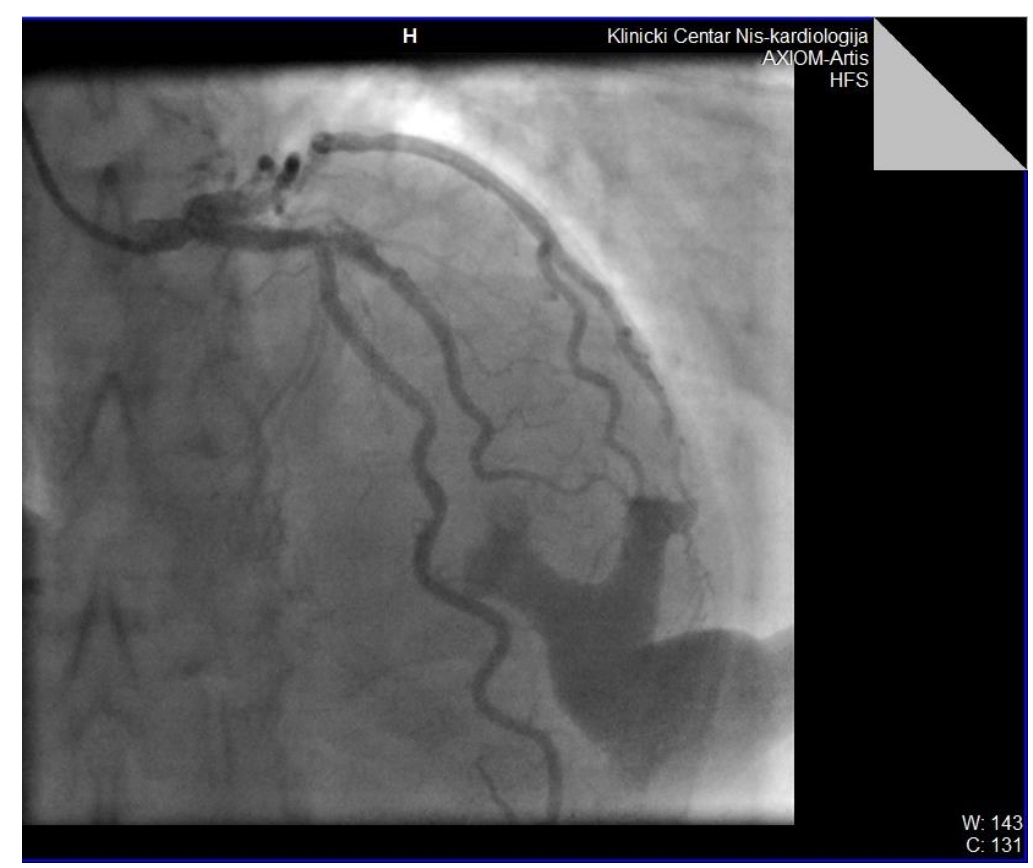

Figure 2. Non-significant lesions in LAD and LCX 
Bare metal stents (BMS) were implanted in the distal, medial, and proximal RCA (Figure 3). During the next 5 days of in-hospital treatment with DAPT, LMWH, BB, ACEI, and statin, the patient was asymptomatic, and was discharged at his own request. Six hours after discharge from the hospital, the patient was readmitted due to the chest pain. ECG showed ST-elevation in inferior leads and in V4R lead, so the angiography procedure was re- peated. It revealed stent thrombosis (Figure 4), but it appeared impossible for the operator to place intermediate coronary wire through in-stent occlusion. In a situation that GP2b3a inhibitors were not available, the only possibility was to administer systemic thrombolysis (TPA). Unfortunately, the patient felt into a shock and comma, and died after only 6 hours.

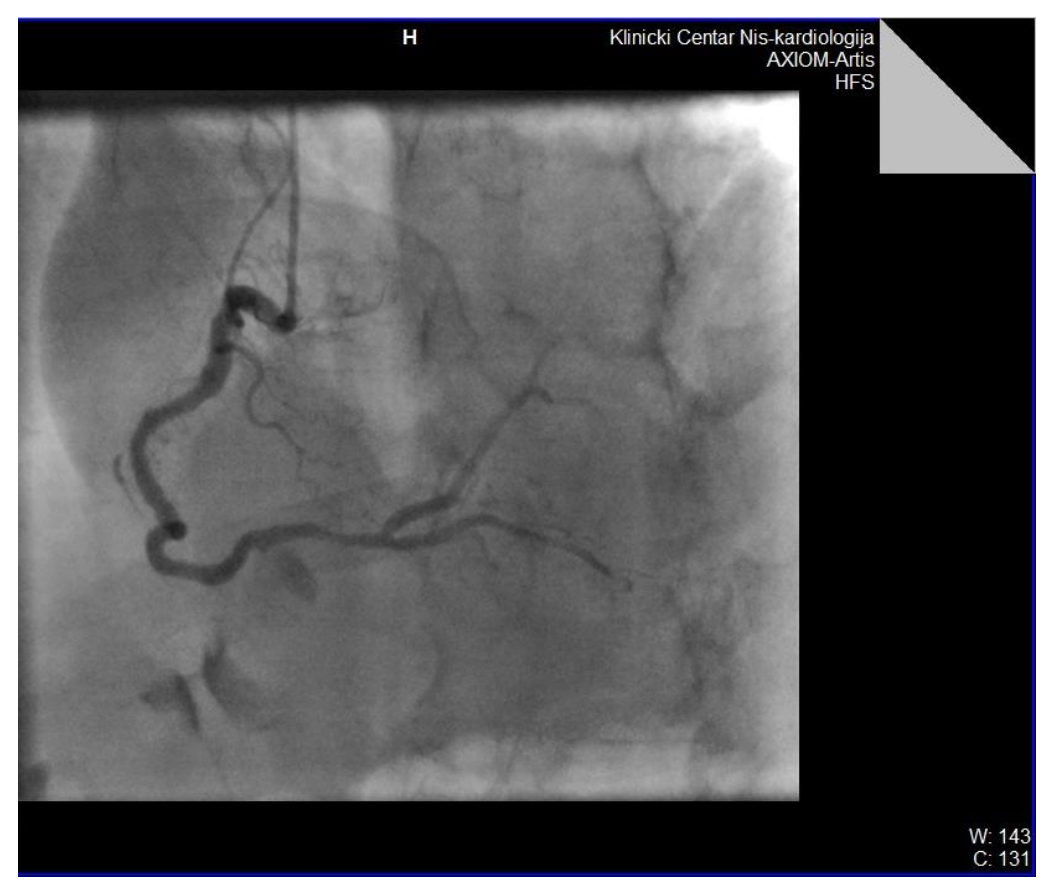

Figure 3. RCA after BMS implantation

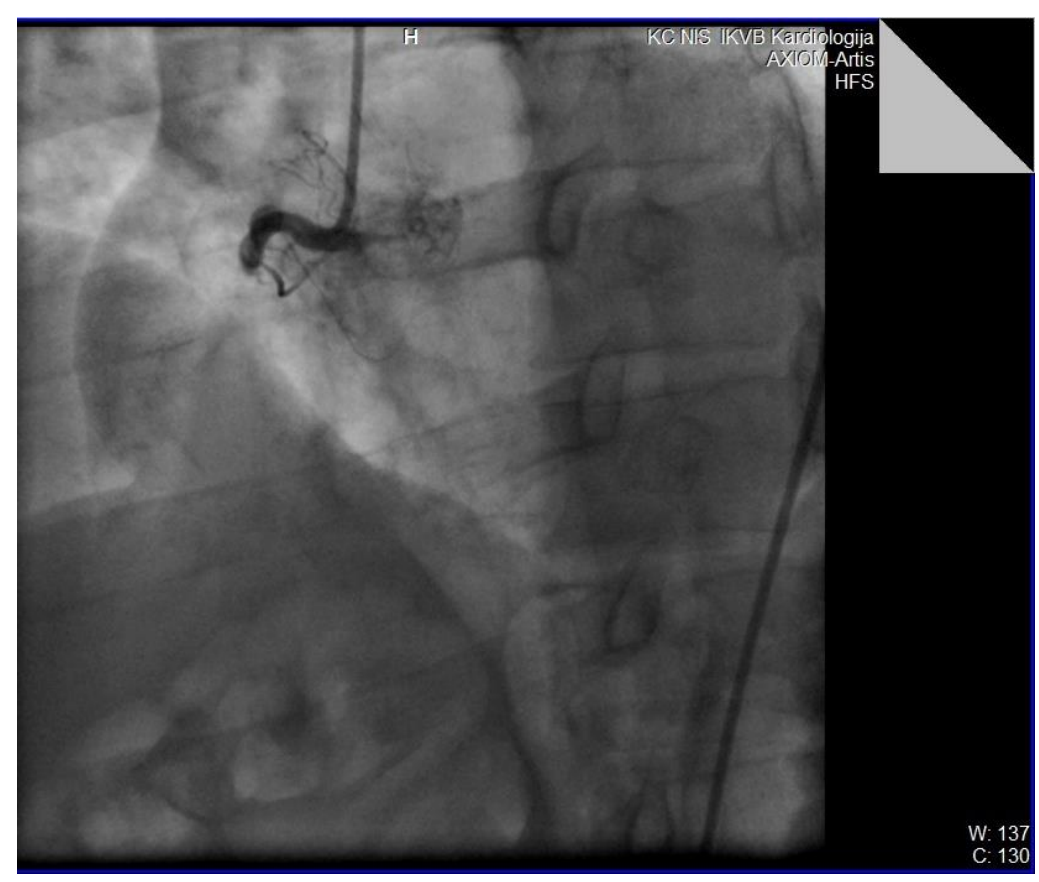

Figure 4. Stent thrombosis in RCA 


\section{Case 2}

A woman, age 58, was admitted to hospital due to severe cough, fatigue, and weight loss, in November 2017. Radiological and MSCT examination revealed a tumor formation in the lungs and liver. Performed pathohistological examination revealed adenocarcinoma bronchogenes with hepatic and pulmonary metastasis. Consequently, the first chemotherapy regimen with paclitaxel and carboplatin was prescribed.

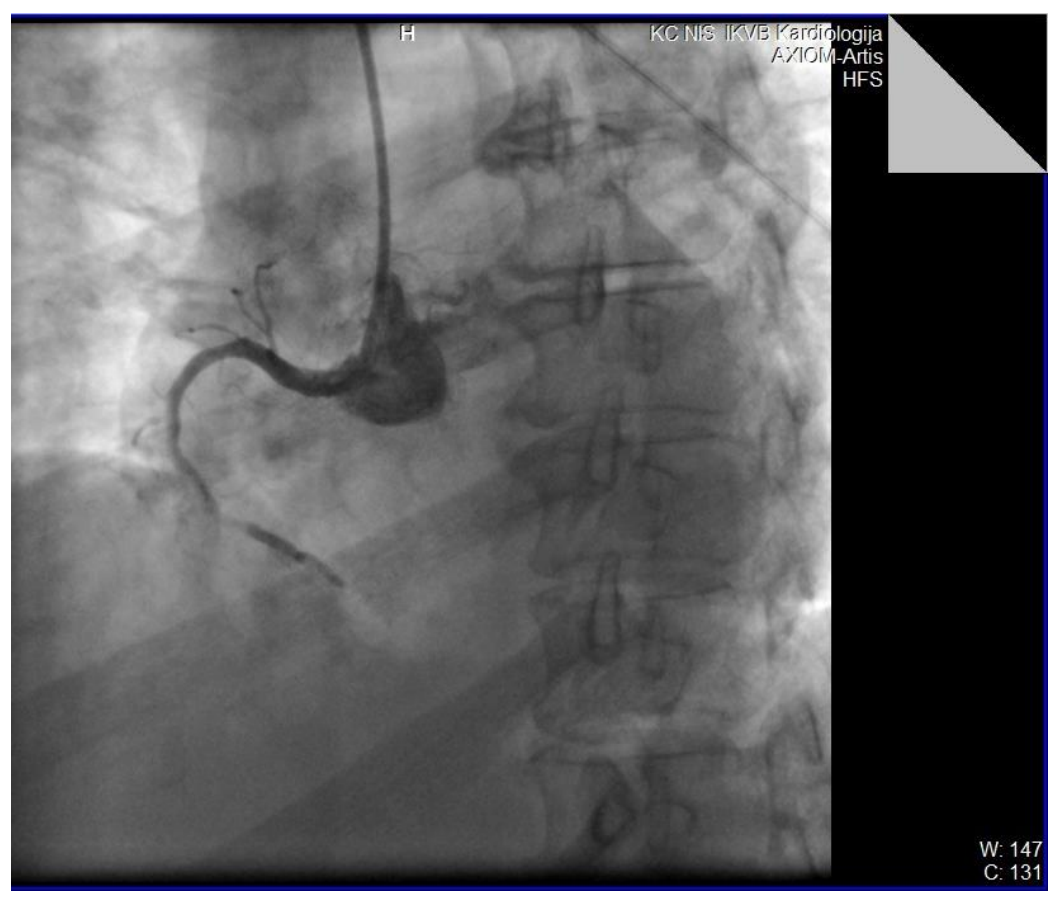

Figure 5. Culprit lesion in distal RCA

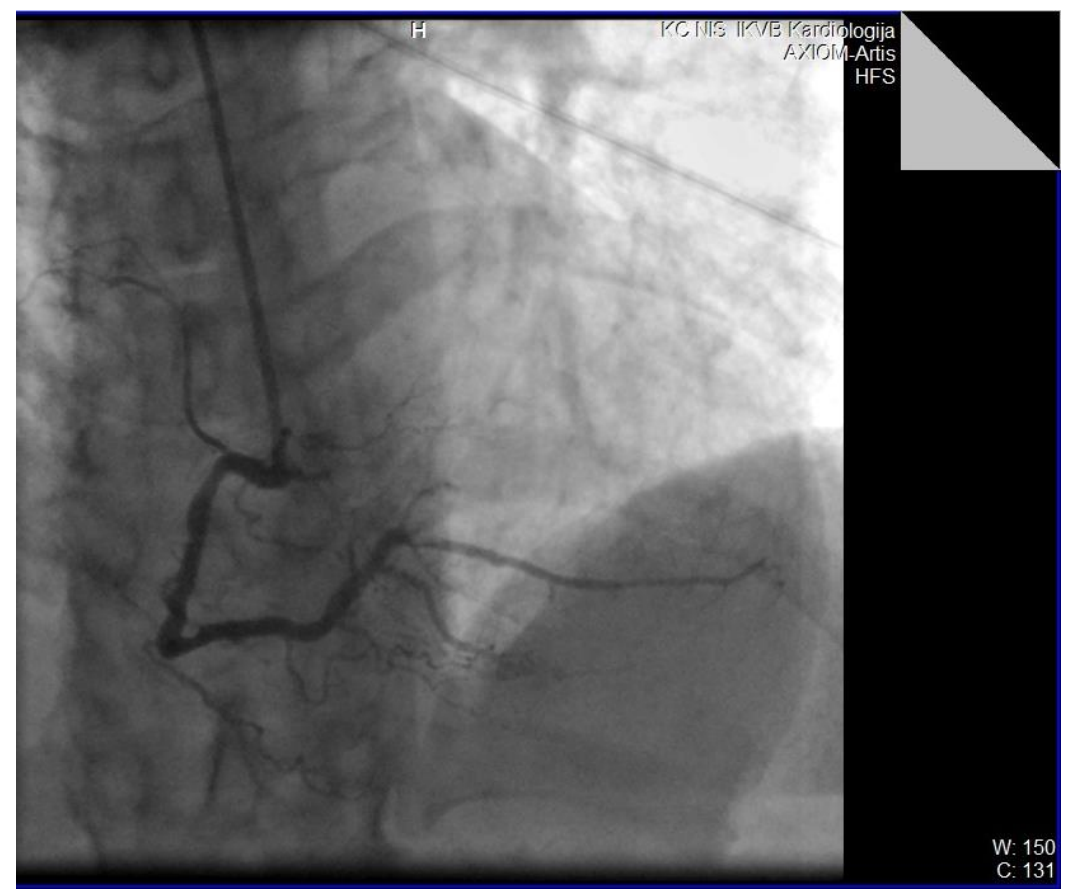

Figure 6. RCA after stent implantation 
Two weeks after the first admission, she came to hospital again. While receiving chemotherapy, the patient felt chest pain and nausea, but the physicians assumed that described symptoms were related to cytostatic drugs application. The next day, she was referred to primary PCI center. ECG on admission showed ST segment elevation in leads II, III, and a VF and ST segment depression in leads V3-V6, with high R-wave, while echocardiography revealed akinesia of the inferior and hypokinesia of the posterior wall of the left ventricle. Culprit lesion in the distal RCA was reached by transradial approach, and BMS was implanted (Figure 5 and 6). The patient was hemodynamically stable during hospitalization, and was discharged after 5 days. Dual antiplatelet therapy was prescribed.

\section{Discussion}

Patients suffering from cancer are on increased risk of CAD and ACS. Chemotherapy and radiation seriously affect coronary arteries, which are the factors that, in association with an increased risk of thrombosis, greatly increase the risk of cardiovascular morbidity with lethal outcome. Conservative treatment of these patients is associated with low survival rate and the best possible therapeutic option for those with good survival prognosis is definitely PCI treatment (1).

An increased risk of ACS in patients suffering from cancer, and those on anti-cancer therapy, is based on abnormal coagulation that is associated with malignancy or antineoplastic therapy, that both increase the risk of thrombosis causing STEMI (4).

Liposarcoma can be very different in type and shape (well/poor differentiated, myxoid/round, pleomorphic), and all of them respond to some extent to chemotherapy, but this response is still not documented very well $(5,6)$. Trabectedin and eribulin have been in use in USA since 2015/2016, in cases of inoperable and/or metastatic liposarcoma and leiomyosarcoma, in patients that have already undergone anthracycline-based treatment $(7,8)$. Our first patient received the synthetic analog of cyclophosphamide ifosfamide. Nevertheless, it was recently shown that some alkylating agents, very similar to cyclophosphamide, such as cisplatin and ifosfamide, may be the cause of heart failure because of some pathological effects, including myocardial ischemia (9).

The patient (Case 2) suffered from bronchogenic adenocarcinoma and she started the chemotherapy with paclitaxel and carboplatin. The patients using paclitaxel rarely develop myocardial infarction (10). Carboplatin, as a derivative of cisplatin, is widely accepted in clinical praxis for its ability to reduce non-hematologic toxicity (11). However, cisplatin is proved to be associated with acute coronary thrombosis, in several vascular areas at the same time $(12,13)$. Cisplatin cause endothelial damage, and influences thromboxane production, platelet activation and aggregation (12, 14, 15). Patients with malignancy, who are treated with platinumbased drugs, have up to 7 time higher long-term risk of CAD and MI $(16,17)$.
Both of our patients were smokers, and both suffered metastatic malignancies, with no other risk factors for the development of CAD. According to Swedish Cancer Registry, that started to collect data in 2002, the risk for patients with metastasis to develop $\mathrm{CHD}$ was increased significantly between 2002 and 2008 (SIR 1.46; 95\% CI 1.28-1.85), but the situation was not the same in patients without metastasis (SIR 0.99; 95\% CI 0.93-1.05) (18). This increased risk for patients to develop CHD is due to different sites and types of cancer they suffer from. Inflammation is seen as one of the possible reasons because of its relation to atherosclerosis and hemostatic activation, while the relation between inflammation and hemostatic activation caused by cancer and CHD is also possible (19-21). Association of metastatic malignancy with $\mathrm{CHD}$ risk has already been observed in clinical practice, in the form of increased inflammation and hemostatic activation in patients with metastases.

In order to avoid ischemic complications caused by excessive coagulation, that is a result of lower fibrinolysis rate and influence of coagulation factors related to malignancy, antithrombotic treatment is an absolute necessity. PCI is seen to be a treatment of choice in cases when cancer is advancing rapidly, or in metastatic situations, when survival rate is expected to be low, i.e., 1 year or less (22). Unfortunately, there are only a few studies that are dealing with the issue of malignancy and PCI treatment (23).

In cases when PCI is a method used to treat CAD in patients with malignancy, both bare BMS and drug-eluting stents (DES) can be used for implantation in coronary arteries, although DES is preferred because of its lower in-stent thrombosis rate. In such PCI procedures, it must be also taken into consideration that hyper-coagulation in conjunction with some special effects in treatment of hematopoietic cells can cause bleeding (24).

Accessing the coronary artery with culprit lesion requires special attention in order to avoid bleeding at site. Complications that might occur are retroperitoneal hemorrhage (RPH), pseudo-aneurysm, artery-venous fistula, excessive bleeding (in thrombocytopenic patients), local infections, and delayed epithelium recovery after application of vascular closure device. In order to access the lesion properly, the procedure must be carefully planned (25).

SCAI recently published a consensus on special considerations for the patients with malignancy who are indicated for the cath lab, recommending a multi-aspect approach for patients with ACS (17). According to these considerations, the type of malignancy and survival prognosis must be taken into account when deciding to undergo PCI. This is of great importance in cases of gastrointestinal cancers because of the higher probability of bleeding in patients receiving antiplatelet and anticoagulation therapy. Also, there is a risk of anemia, a prediction of heart failure and lethal outcome in patients with STEMI, and thrombocytopenia which is followed by the increased bleeding risk $(1,17)$. 


\section{Conclusion}

Patients suffering from cancer associated with STEMI are very challenging for all physicians, especially cardiologists. It is well known that the same loading DAPT, culprit lesion, and percutaneous procedure in different cases could have various outcomes along with possible complications. Malignancy and CAD are interrelated, but the exact type of malignancy and its metastasis is of great importance in assessing different survival rate for different patients.

\section{Conflict of Interest Statement}

The authors declare no conflicts of interest.

\section{References}

1. Iliescu C, Tsitlakidou D, Giza DE, Marmagkiolis K. Primary Percutaneous Coronary Interventions in Cancer Patients. Cancer Research Frontiers 2017;3: 64-71. [CrossRef]

2. Yusuf SW, Cipolla C, Durand JB, Lenihan DJ. Cancer and cardiovascular disease. Cardiol Res Pract 2011; 2011:943748. [CrossRef] [PubMed]

3. Khakoo AY, Yeh ET. Therapy insight: Management of cardiovascular disease in patients with cancer and cardiac complications of cancer therapy. Nat Clin Pract Oncol 2008;5:655-67. [CrossRef] [PubMed]

4. Blann AD, Dunmore S. Arterial and venous thrombosis in cancer patients. Cardiol Res Pract 2011;2011: 394740. [CrossRef] [PubMed]

5. Mateva SA, Nikolova MR, Valkov AV, TodorovaDoneva JM. Well-differentiated liposarcoma of the larynx: a case report and review of literature. J Biomed Clin Res 2016;9:85-89. [CrossRef]

6. Jones RL, Fisher C, Al-Muderis O, Judson IR. Differential sensitivity of liposarcoma subtypes to chemotherapy. Eur ] Cancer 2005;41:2853-60. [CrossRef] [PubMed]

7. Demetri GD, von Mehren $M$, Jones RL, Leigh Hensley $M$, Schuetze S, Staddon AP, et al. A randomized phase III study of trabectedin (T) or dacarbazine (D) for the treatment of patients (pts) with advanced liposarcoma (LPS) or leiomyosarcoma (LMS). Abstract 10503. Presented at American Society of Clinical Oncology (ASCO) Annual Meeting, Chicago, IL, 2015. [CrossRef]

8. Halaven [package insert]. Woodcliff Lake, $\mathrm{NJ}$; Eisai Inc; October 2016. Accessed:1.11. 2018.

9. Zamorano JL, Lancellotti P, Muñoz DR, Aboyans V Asteggiano R, Galderisi M. 2016 ESC Position Paper on cancer treatments and cardiovascular toxicity developed under the auspices of the ESC Committee for Practice Guidelines. Eur Heart J 2016;37:2768-801. [CrossRef] [PubMed]

10. Shah K, Gupta S, Ghosh J, Bajpai J, Maheshwari A. Acute non-ST elevation myocardial infarction following paclitaxel administration for ovarian carcinoma: A case report and review of literature. J Cancer Res Ther 2012;8:442-4. [CrossRef] [PubMed]
11. Cheng YJ, Wu R, Cheng ML, Du J, Hu XW, Yu L, et al. Carboplatin-induced hematotoxicity among patients with nonsmall cell lung cancer: Analysis on clinical adverse events and drug-gene interactions. Oncotarget 2017;8:32228-36. [CrossRef] [PubMed]

12. Jafri M, Protheroe A. Cisplatin-associated thrombosis. Anticancer Drugs 2008;19:927-9. [CrossRef] [PubMed]

13. Karabay KO, Yildiz O, Aytekin V. Multiple coronary thrombi with cisplatin. J Invasive Cardiol 2014;26: E18-E20. [PubMed]

14. Togna GI, Togna AR, Franconi M, Caprino L. Cisplatin triggers platelet activation. Thromb Res 2000;99: 503-9. [CrossRef] [PubMed]

15. Ito D, Shiraishi J, Nakamura T, Maruyama N, Iwamura $Y$, Hashimoto S, et al. Primary percutaneous coronary intervention and intravascular ultrasound imaging for coronary thrombosis after cisplatin-based chemotherapy. Heart Vessels 2012;27:634-8. [CrossRef] [PubMed]

16. Feldman DR, Schaffer WL, Steingart RM. Late cardioascular toxicity following chemotherapy for germ cell tumors. J Natl Compr Canc Netw 2012;10:537-44. [CrossRef] [PubMed]

17. Iliescu CA, Grines CL, Herrmann J, Yang $E H$, Cilingiroglu $M$, Charitakis $K$, et al. SCAI Expert Consensus Statement: Evaluation, Management, and Special Considerations of Cardio-Oncology Patients in the Cardiac Catheterization Laboratory (Endorsed by the Cardiological Society of India, and Sociedad Latino Americana de Cardiologia Intervencionista). Catheter Cardiovasc Interv 2016;87:E202-E23. [CrossRef] [PubMed]

18. Zöller $B$, Ji J, Sundquist J, Sundquist K. Risk of coronary heart disease in patients with cancer: A nationwide follow-up study from Sweden. EJC 2012; 48:121-8. [CrossRef] [PubMed]

19. Coussens LM, Werb Z. Inflammation and cancer. Nature 2002;420:860-7. [CrossRef] [PubMed]

20. $\mathrm{Xu} \mathrm{J}$, Lupu F, Esmon CT. Inflammation, innate immunity and blood coagulation. Hamostaseologie 2010;30:8-9. [CrossRef] [PubMed] 
21. Libby P. Inflammation in atherosclerosis. Nature 2002; 420:868-74. [CrossRef] [PubMed]

22. van Leuven SI, Franssen R, Kastelein JJ, Levi M, Stroes ES, Tak PP. Systemic inflammation as a risk factor for atherothrombosis. Rheumatology 2008;47: 3-7. [CrossRef] [PubMed]

23. Krone RJ. Managing coronary artery disease in the cancer patient. Prog Cardiovasc Dis 2010;53:149-156. [CrossRef] [PubMed]

24. Velders $M A$, Boden $H$, Hofma $S H$, Osanto $S$, van der Hoeven BL, Heestermans AA, et al. Outcome after ST elevation myocardial infarction in patients with cancer treated with primary percutaneous coronary intervention. Am J Cardiol 2013;112:1867-72.

[CrossRef] [PubMed]

25. Nathan S, Rao SV. Radial versus femoral access for percutaneous coronary intervention: implications for vascular complications and bleeding. Curr Cardiol Rep 2012;14:502-9. [CrossRef] [PubMed]

\title{
BOLESNICI SA RAZLIČITIM METASTATSKIM MALIGNITETIMA I AKUTNIM INFARKTOM MIOKARDA SA ELEVACIJOM ST SEGMENTA TRETIRANI PRIMARNOM PERKUTANOM KORONARNOM INTERVENCIJOM
}

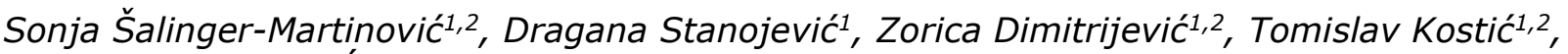 \\ Snežana Ćirić-Zdravković1,2, Branislava Ivanović ${ }^{3,4}$, Stefan Momčilović ${ }^{5}$
}

\author{
${ }^{1}$ Klinika za kardiovaskularne bolesti, Klinički centar Niš, Niš, Srbija \\ 2Univerzitet u Nišu, Medicinki fakultet, Katedra za kardiologiju, Niš, Srbija \\ ${ }^{3}$ Univerzitet u Beogradu, Medicinski fakultet, Beograd, Srbija \\ ${ }^{4}$ Klinika za kardiologiju, Klinički centar Srbije, Beograd, Srbija \\ 5Univerzitet u Nišu, Medicinki fakultet, Niš, Srbija
}

Kontakt: Sonja Šalinger-Martinović

Bulevar dr Zorana Đinđića 48, 18000 Niš, Srbija

E-mail: sonja.salinger@gmail.com

\begin{abstract}
Kardiovaskularne bolesti i maligniteti predstavljaju, i dalje, najčešće potencijalne uzroke smrtnog ishoda. Ove bolesti vrlo često koegzistiraju u starijoj populaciji i proizilaze iz istih faktora rizika, kao što je konzumiranje duvana. Napredak u tretmanu maligniteta produžava životni vek, ali isto tako hemioterapija i radioterapija mogu dovesti do raznih oštećenja na nivou organizma. Primena mnogih hemoterapeutika udružena je sa razvojem angine pektoris i infarkta miokarda, dok je radioterapija udružena sa razvojem koronarne bolesti, preko direktnog oštećenja endotela. Pored toga, protrombotski i inflamatorni status u malignim bolestima podstiču razvoj aterosklerotskih plakova i formiranje tromba u koronarnim arterijama. $U$ ovom radu prezentovali smo dva bolesnika sa različitim metastatskim malignitetima i akutnim infarktom miokarda sa ST elevacijom, koji su bili lečeni primarnom perkutanom koronarnom intervencijom (pPCI) i imali različite kratkoročne kliničke ishode.
\end{abstract}

Acta Medica Medianae 2020;59(2):125-131.

Ključne reči: malignitet, infarkt miokarda, PCI, ishod 